Bài báo khoa học

\title{
Xây dựng bản đồ phân bố cấp độ tác động của biến đổi khí hậu đến quy hoạch, thăm dò, khai thác, chế biến và sử dụng các khoáng sản chủ yếu ở Việt Nam
}

\author{
Trương Thị Thanh Thủy ${ }^{1 *}$, Vũ Văn Thăng ${ }^{1}$, Nguyễn Hữu Quyền ${ }^{1}$, Nguyễn Trọng Hiệu ${ }^{2}$, \\ Trần Duy Hiền ${ }^{3}$, Lại Hồng Thanh ${ }^{4}$ \\ ${ }^{1}$ Viện Khoa học Khí tượng Thủy văn và Biến đổi khí hậu; thuytruong021088@gmail.com \\ ${ }^{2}$ Trung tâm Khoa học công nghệ Khí tượng Thủy văn và Môi trường; hieu.nt38@gmail.com \\ ${ }^{3}$ Vụ Khoa học và Công nghệ; tranhienvkttv@gmail.com \\ ${ }^{4}$ Tổng cục Địa chất và Khoáng sản Việt Nam; lhthanh@monre.gov.vn \\ * Tác giả liên hệ: thuytruong021088@gmail.com; Tel: +84-364396626
}

Ban Biên tập nhận bài: 25/10/2020; Ngày phản biện xong: 27/11/2020; Ngày đăng bài: $25 / 12 / 2020$

Tóm tắt: Trong nghiên cứu này, bộ số liệu kịch bản $\mathrm{BĐKH} \mathrm{và} \mathrm{nước} \mathrm{biển} \mathrm{dâng} \mathrm{do} \mathrm{Bộ} \mathrm{tài}$ nguyên và Môi trường công bố năm 2016 được sử dụng cho mục đích nghiên cứu. Kết quả xây dựng bản đồ cho thấy, trong quy hoạch, thăm dò, khai thác, chế biến và sử dụng các khoáng sản than, bauxit, chì-kẽm, đá vôi xi măng, đá vôi trắng, kaolin, felspat, apatit, đá làm vật liệu xây dựng thông thường, cần đặc biệt lưu ý đến các biện pháp phòng chống lạnh ở Lai Châu, Lào Cai, Sơn La, Lâm Đồng và các biện pháp phòng chống nóng ở vùng Đồng bằng Bắc Bộ, Trung Bộ, Nam Bộ; Phòng chống mưa lớn ở các mỏ thuộc phía nam khu mỏ Hà Giang và khu vực Thừa Thiên Huế -Quảng Ngãi. Cần lưu ý đến nhiệt độ cao nhất trong các tháng mùa hè ở Bắc Bộ và Trung Bộ; các cực trị mưa vào các tháng mùa mưa ở các mỏ thuộc Hà Giang, Yên Bái, ven biển Bắc Bộ, khu vực Trung Bộ, Đắc Lắc theo kịch bản RCP4.5 và ở các mỏ thuộc Đông Bắc Bộ, Trung Bộ theo kịch bản RCP8.5. Đối với việc quy hoạch, khai thác, chế biển, sử dụng khoáng sản Titan-Zircon cần đặc biệt lưu ý đến nguy cơ ngập ở khu vực Quảng Bình đến Thừa Thiên Huế.

Từ khóa: Bản đồ; BĐKH; Khoáng sản; Việt Nam.

\section{Giới thiệu}

Nằm trong vành đai sinh khoáng Châu Á-Thái Bình Dương, Việt Nam có nguồn tài nguyên khoáng sản (TNKS) đa dạng và phong phú với trên 5000 mỏ, điểm quặng của trên 60 loại khoáng sản khác nhau [1]. Đến nay, TNKS đã trở thành một trong những nguồn lực quan trọng để phát triển kinh tế-xã hội đất nước, cung cấp nhiều nguyên liệu cho chế biến các thiết bị mà chúng ta sử dụng hàng ngày như lon nhôm, chip điện tử của điện thoại di động, máy tính,....và là động lực để thúc đẩy các ngành công nghiệp khác phát triển. Tuy nhiên, khoáng sản là loại tài nguyên không tái tạo, việc khai thác và sử dụng chúng không chỉ đáp ứng các tiêu chí như khai thác triệt để, sử dụng hiệu quả, tiết kiệm mà cần phải tính đến vấn đề thích ứng với biến đổi khí hậu $(\mathrm{BĐKH})$, hạn chế tác động xấu đến môi trường. Trong bối cảnh biến đổi khí hậu như hiện nay, tần suất và cường độ của các cực đoan khí hậu có sự gia tăng, gây ảnh hưởng tiêu cực đến việc thăm dò, khai thác, chế biến và sử dụng khoáng sản [2-4]. Điều này đặt ra yêu cầu cấp thiết trong việc nghiên cứu về tác động của BĐKH cũng như xây dựng các biện pháp thích ứng và giảm thiểu tác động của $\mathrm{BĐKH} \mathrm{tới}$ hoạt động khai thác khoáng sản. Cho đến nay, hướng nghiên cứu này còn rất hạn chế. Vì vậy, 
việc nghiên cứu xây dựng: "Tập bản đồ phân bố cấp độ tác động của BĐKH đến quy hoạch, thăm dò, khai thác, chế biến và sử dụng các khoáng sản chủ yếu ở Việt Nam" là cần thiết, tạo điều kiên thuận lợi cho việc thực hiện quy hoạch phát triển ngành công nghiệp khai khoáng, cũng như khai thác sử dụng hợp lý, có hiệu quả nguồn TNKS, bảo vệ môi trường và hạn chế được những rủi ro trong tương lai. Tập bản đồ bao gồm 8 bản đồ phản ánh mức độ tác động của biến đồi nhiệt độ và lượng mưa theo hai kịch bản RCP4.5 và RCP8.5 trong giai đoạn đầu thế kỷ 21 (2016-2035) đối với 9 loại khoáng sản là: than, bauxit, chì-kẽm, đá vôi xi măng, đá vôi trắng, kaolin, felspat, apatit, đá làm vật liệu xây dựng thông thường; và 1 bản đồ nguy cơ ngập úng với mực nước biển dâng $100 \mathrm{~cm}$ trên khu vực Ven biển Miền Trung có khoáng sản titan-zircon.

\section{Phương pháp và số liệu nghiên cứu}

\subsection{Phuơng pháp nghiên cúu}

\subsubsection{Phương pháp thiết lập bản đồ nền}

- Bản đồ nền được thiết lập theo Thông tư 47/2014/TT-BTNMT Quy định kỹ thuật thành lập bản đồ hành chính các cấp [5].

- Khung và trình bày khung theo bản đồ do Bộ Nội vụ cung cấp. Tọa độ gốc khung của bản đồ được thể hiện trong hình 1 .

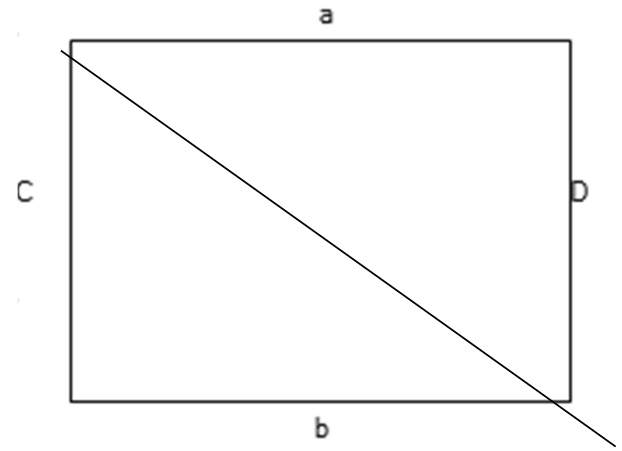

$\mathrm{A}=24.171952299^{\circ} \mathrm{Bắc} ; \mathrm{b}=4.828047701^{\circ} \mathrm{Bắc} ; \mathrm{C}=101.855199958^{\circ}$ Đông; $\mathrm{d}=118.144800042^{\circ}$ Đông

Hình 1. Tọa độ góc khung của bản đồ.

- Bản đồ hành chính toàn quốc sử dụng lưới chiếu hình nón đứng đồng góc với các thông số: 2 vĩ tuyến chuẩn là $11^{\circ}$ vĩ độ Bắc, $21^{\circ}$ vĩ độ Bắc; kinh tuyến trục $108^{\circ}$ kinh độ Đông; vĩ tuyến gốc $4^{\circ}$ vĩ độ Bắc. Bản đồ hành chính cấp tỉnh, bản đồ hành chính cấp huyện áp dụng Hệ quy chiếu và Hệ tọa độ quốc gia VN-2000: Ê-líp-xô-ít WGS-84 toàn cầu; bán trục lớn là $6378137,0 \mathrm{~m}$; độ dẹt là 1:298,257223563; sử dụng lưới chiếu hình trụ ngang đồng góc với múi chiếu $6^{\circ}$ có hệ số điều chỉnh tỷ lệ biến dạng chiều dài $\mathrm{k}_{0}=0,9996$.

- Các lớp thông tin nền bao gồm Khung trong bản đồ; lưới kinh tuyến vĩ tuyến; các điểm tọa độ, độ cao quốc gia; ghi chú tỷ lệ, thước tỷ lệ. Yếu tố hành chính: Biên giới quốc gia và địa giới hành chính. Yếu tố nền địa lý: Thủy văn; địa hình; dân cư; kinh tế-xã hội; giao thông.

- Bản đồ số được thực hiện ở Tỷ lệ 1: 250 000; Bản đồ giấy được hiển thị theo tỷ lệ phù hợp khi thu về khổ giấy $\mathrm{A} 0, \mathrm{~A} 3$ và $\mathrm{A} 4$ để thuận tiện cho việc in ấn và đáp ứng các mục đích sử dụng khác nhau. Kích thước của bản đồ bao gồm các kích thước của khung trong, khung ngoài và kích thước của tờ giấy in bản đồ.

2.1.2. Phương pháp xây dựng bản đồ cấp độ tác động của biến đổi khí hậu, nước biển dâng

a) Nhóm bản đồ kịch bản $B Đ K H$

Bản đồ cấp độ tác động của biến đổi khí hậu đến các hoạt động khai khoáng được thực hiện theo các bước sau: 
Bước 1: Nghiên cứu phân cấp trị số của 4 yếu tố khí hậu đã dược chỉ định xây dựng bản đồ và đưa kết quả phân cấp vào các bảng (bảng 1 , bảng 2 và bảng 3 ).

Bước 2: Xác định và đánh dấu vị trí của các điểm khai thác mỏ trên bản đồ nền.

Bước 3: Lựa chọn trạm khí tượng gần nhất đại diện cho điểm khai thác mỏ về trị số của yếu tố khí hậu theo kịch bản khí hậu.

Bước 4: Xác định cấp độ tác động của biến đổi khí hậu cho từng trạm khí tượng đại diện về 4 yếu tố khí hậu theo các bảng phân cấp nói trên.

Bước 5: Gán cấp tác động của biến đổi khí hậu của trạm khí tượng đại diện cho điểm khai thác mỏ.

Bước 6: Quy định thang màu tương ứng với cấp độ tác động.

Bảng 1. Phân cấp nhiệt độ trung bình năm (Ttb năm) [4].

\begin{tabular}{cccc}
\hline $\begin{array}{c}\text { Khoảng giá trị } \\
\text { Ttb năm }\left({ }^{\circ} \mathrm{C}\right)\end{array}$ & Cấp & $\begin{array}{c}\text { Khoảng giá trị } \\
\text { Ttb năm }\left({ }^{\circ} \mathrm{C}\right)\end{array}$ & Cấp \\
\hline$\leq 18,0$ & 1 & $23,1-24,0$ & 7 \\
$18,1-19,0$ & 2 & $24,1-25,0$ & 8 \\
$19,1-20,0$ & 3 & $25,1-26,0$ & 9 \\
$20,1-21,0$ & 4 & $26,1-27,0$ & 10 \\
$21,1-22,0$ & 5 & $>27,0$ & 11 \\
$22,1-23,0$ & 6 & & \\
\hline
\end{tabular}

Bảng 2. Phân cấp lượng mưa năm (Rnăm) [4].

\begin{tabular}{cccc}
\hline Khoảng giá trị Rnăm $(\mathrm{mm})$ & Cấp & Khoảng giá trị Rnăm $(\mathrm{mm})$ & Cấp \\
\hline$\leq 1400,0$ & 1 & $3000,1-3400,0$ & 6 \\
$1400,1-1800,0$ & 2 & $3400,1-3800,0$ & 7 \\
$1800,1-2200,0$ & 3 & $3800,1-4200,0$ & 8 \\
$2200,1-2600,0$ & 4 & $4200,1-4600,0$ & 9 \\
$2600,1-3000,0$ & 5 & $>4600,0$ & 10 \\
\hline
\end{tabular}

Bảng 3. Phân cấp TXx năm và Rx1day năm [4].

\begin{tabular}{ccccc}
\hline TXx năm & \multicolumn{3}{c}{ Rx1day năm } \\
\hline Khoảng giá trị $\left({ }^{\circ} \mathrm{C}\right)$ & Cấp & Khoảng giá trị $(\mathrm{mm})$ & Cấp & Ý nghĩa \\
\hline$<38$ & 1 & $\leq 100,0$ & 1 & Rất nhỏ \\
$38-39$ & 2 & $100,1-200,0$ & 2 & Nhỏ \\
$39-40$ & 3 & $200,1-300,0$ & 3 & Vừa phải \\
$40-41$ & 4 & $300,1-400,0$ & 4 & Lớn \\
$41-42$ & 5 & $400,1-500,0$ & 5 & Rất lớn \\
$>42$ & 6 & $>500,0$ & 6 & Đặc biệt lớn \\
\hline
\end{tabular}

\section{b) Bản đồ nguy cơ ngập đối với khoáng sản titan-zircon}

Bản đồ nguy cơ ngập được xây dựng ứng với giả định mực nước biển dâng $100 \mathrm{~cm}$ trên khu vực ven biển miền Trung có khoáng sản titan-zircon được xây dựng theo các bước sau đây:

Bước1: Xác định và đánh dấu vị trí của các điểm khai thác mỏ trên bản đồ nền.

Bước 2: Lựa chọn đoạn bờ biển đại diện cho điểm khai thác mỏ về mức độ ngập theo kịch bản biến đổi khí hậu.

Bước 3: Xác định mức độ ngập cho từng đoạn bờ biển đại diện.

Bước 4: Gán mức độ ngập của đoạn bờ biển đại diện cho điểm khai thác mỏ.

Bước 5: Quy định thang màu tương ứng với cấp độ ngập và biểu thị mức độ ngập theo thang màu đã quy định cho từng điểm khại thác mỏ theo vị trí trên bản đồ. 


\subsection{Số liệu nghiên cúu}

- Số liệu nhiệt độ, lượng mưa trong tương lai theo các kịch bản RCP4.5, RCP8.5 và số liệu mực nước biển dâng được lấy từ "Kịch bản biến đổi khí hậu và nước biển dâng cho Việt Nam" năm 2016 [6]; Bộ bản đồ hành chính Việt Nam.

\section{Kết quả và thảo luận}

\subsection{Cấp độ tác động của các biến khí hậu trung bình}

\subsubsection{Nhiệt độ trung bình năm}

Theo kịch bản RCP4.5, vào đầu thế kỷ 21 , nhiệt độ trung bình năm phổ biến đạt cấp: 18 ở vùng mỏ Tây Bắc và Đông Bắc, 7-8 ở vùng mỏ Đồng bằng Bắc Bộ, cấp 8-9 ở vùng mỏ Bắc Trung Bộ, cấp 9-11 ở vùng mỏ Nam Trung Bộ, cấp 2-10 ở vùng mỏ Tây Nguyên và cấp 10-11 ở vùng mỏ Nam Bộ. Phân bố cấp độ tác động của nhiệt độ trung bình năm theo kịch bản RCP8.5 tương tự kịch bản RCP4.5 tại hầu hết vùng mỏ, riêng nhiệt độ tại vùng mỏ Đồng bằng Bắc Bộ đạt cấp 8 vào đầu thế kỷ 21 (Hình 2). Trong quá trình khai thác các mỏ, cần lưu ý phòng chống lạnh (nhiệt độ trung bình năm $\leq$ cấp 2) ở một vài nơi thuộc các tỉnh Lai Châu, Lào Cai, Sơn La (Tây Bắc Bộ), Lâm Đồng (Tây Nguyên) và cần có các biện pháp phòng chống nóng (nhiệt độ trung bình năm $\geq$ cấp 8 ) khi khai thác các mỏ thuộc Đồng bằng Bắc Bộ, Trung Bộ, Nam Bộ.

\subsubsection{Lượng mưa năm}

Theo kịch bản RCP4.5, vào đầu thế kỷ 21 , lượng mưa năm đạt cấp 1-5 ở vùng mỏ Tây Bắc, cấp 1-10 ở vùng mỏ Đông Bắc, cấp 2-3 ở vùng mỏ Đồng bằng Bắc Bộ, cấp 2-9 ở vùng mỏ Bắc Trung Bộ, cấp 1-10 ở vùng mỏ Nam Trung Bộ, cấp 2-6 ở vùng mỏ Tây Nguyên và cấp 3-5 ở vùng mỏ Nam Bộ. Theo kịch bản RCP8.5, vào đầu thế kỷ 21 , phân bố phạm vi cấp độ tác động của lượng mưa năm tương tự RCP4.5 tại các vùng mỏ Tây Bắc, Đông Bắc, Tây Nguyên, đạt cấp 2-4 ở vùng mỏ Đồng bằng Bắc Bộ, cấp 2-10 ở vùng mỏ Bắc Trung Bộ, cấp 2-10 ở vùng mỏ Nam Trung Bộ và cấp 3-6 ở vùng mỏ Nam Bộ (Hình 3). Trong quá trình khai thác cần đặc biệt lưu ý phòng chống mưa lớn ở các mỏ thuộc phía nam khu mỏ Hà Giang (lượng mưa năm đạt cấp 10) và khu vực Thừa Thiên Huế -Quảng Ngãi (lượng mưa năm phổ biến cấp 6-10).
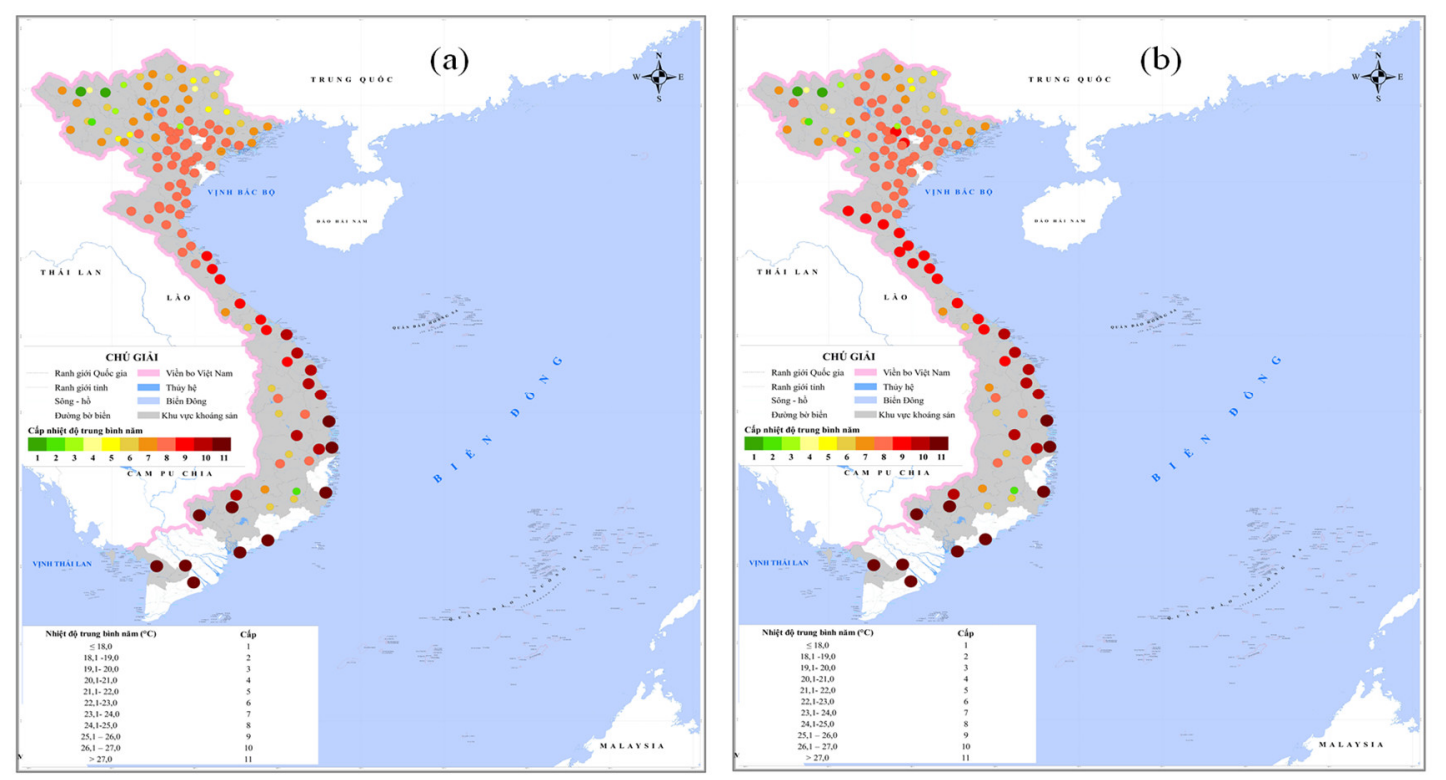

Hình 2. Bản đồ phân bố cấp độ tác động của nhiệt độ trung bình năm thời kỳ 2016-2035 theo kịch bản RCP4.5 (a) và RCP8.5 (b) tại khu vực có khoáng sản trên khu vực Việt Nam. 

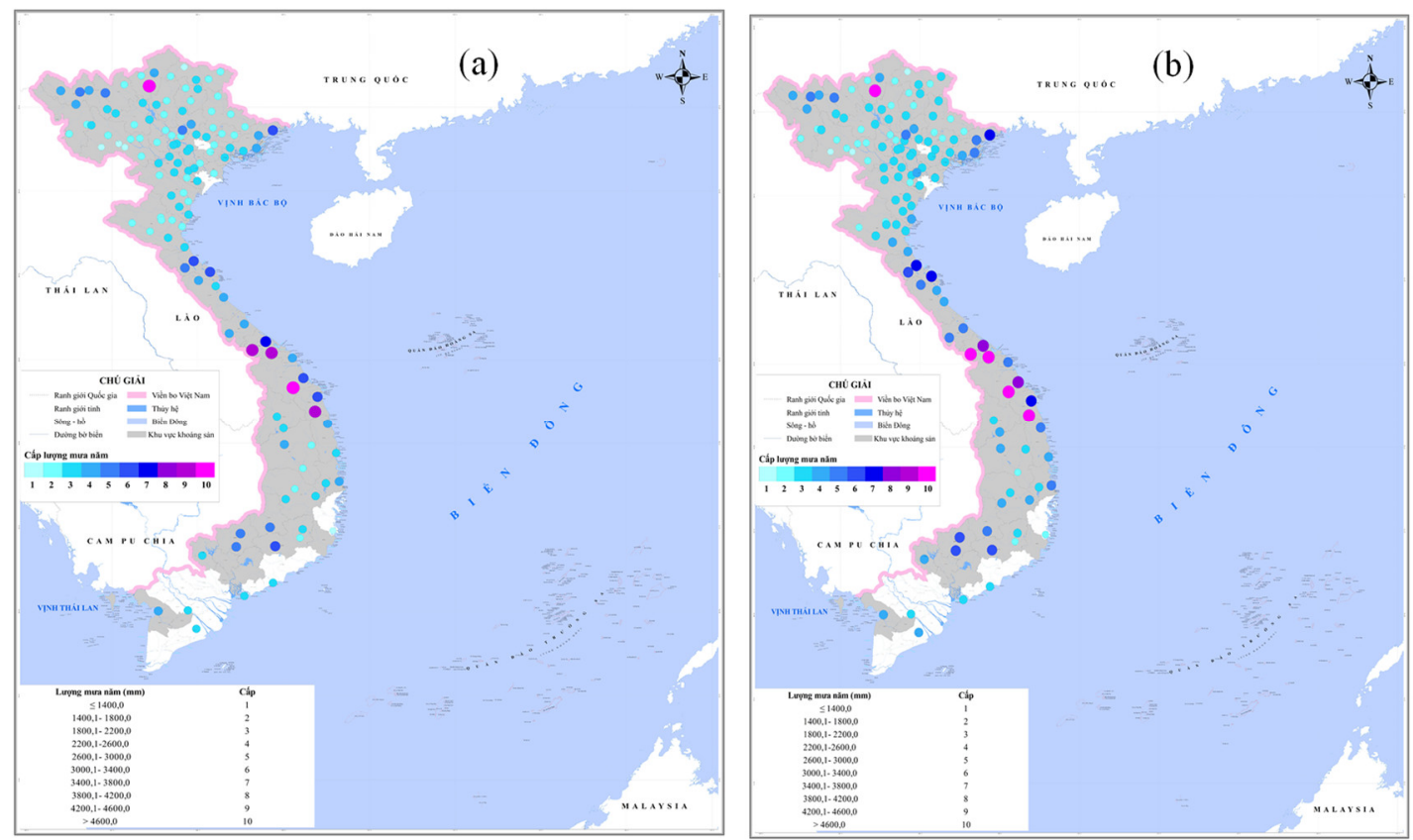

Hình 3. Bản đồ phân bố cấp độ tác động của lượng mưa năm thời kỳ 2016-2035 theo kịch bản RCP4.5 (a) và RCP8.5 (b) tại khu vực có khoáng sản trên khu vực Việt Nam.

\subsection{Cấp độ tác động của các biến khí hậu cực trị}

a) Nhiệt độ cao nhất tuyệt đối năm (TXx năm)

Theo kịch bản RCP4.5, vào đầu thế kỷ 21 , nhiệt độ cao nhất tuyệt đối năm đạt cấp 1-6 ở các vùng mỏ Tây Bắc, Đông Bắc, Bắc Trung Bộ, cấp 3-6 ở vùng mỏ Đồng bằng Bắc Bộ, Nam Trung Bộ, cấp 1-4 ở vùng mỏ Tây Nguyên, cấp 1-5 ở vùng mỏ Đông Nam Bộ và chỉ khoảng cấp 1 ở vùng mỏ Tây Nam Bộ. Theo kịch bản RCP8.5, vào đầu thế kỷ 21 , phân bố phạm vi cấp độ tác động của TXx năm tương tự kịch bản RCP4.5 tại hầu hết vùng mỏ, riêng vùng mỏ Tây Nam Bộ đạt cấp 1-2 (Hình 3). Cần đặc biệt lưu ý về nhiệt độ cao nhất trong hoạt động khai thác, chế biến khoáng sản trong các tháng mùa hè ở Bắc Bộ và Trung Bộ.

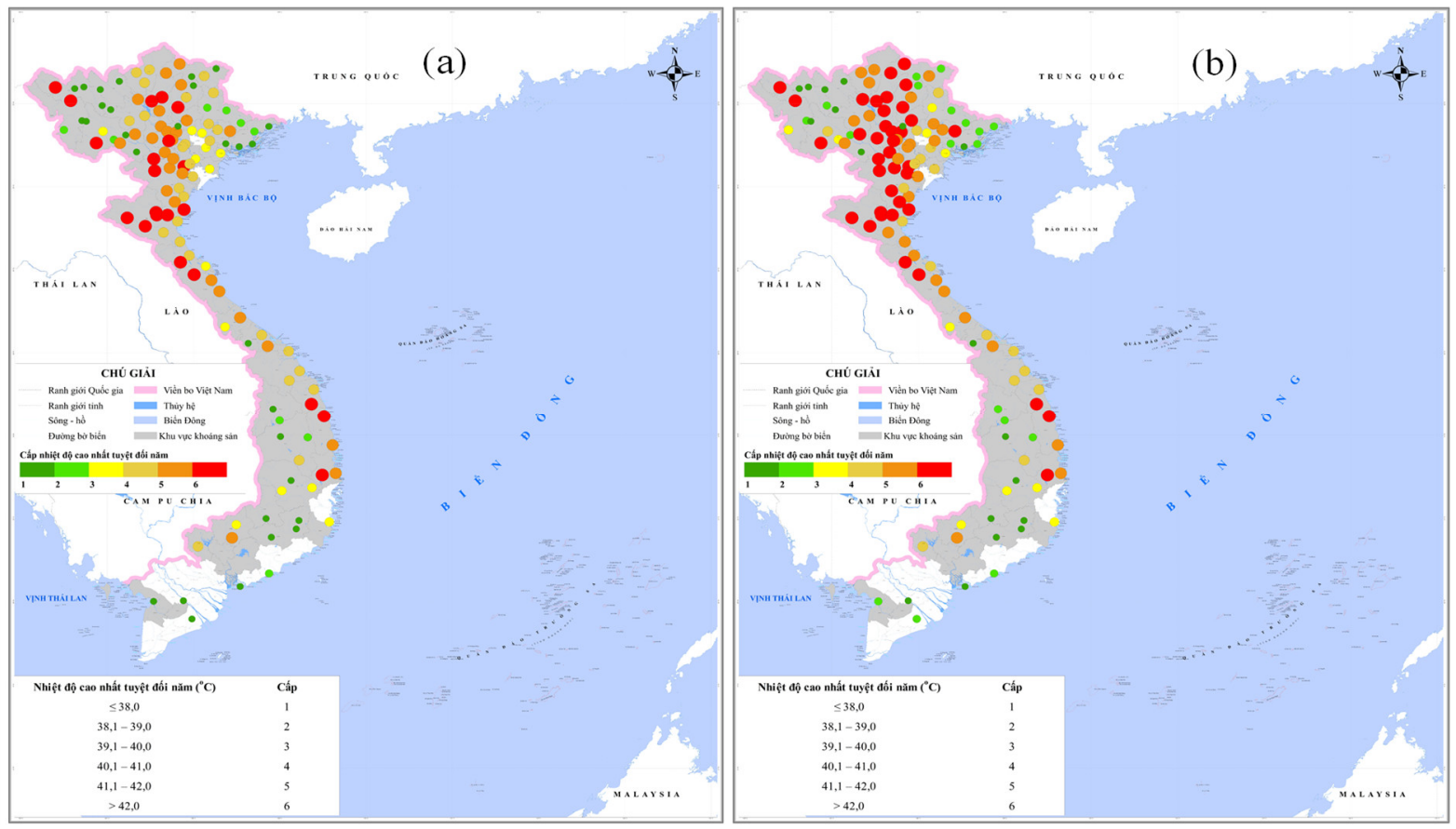

Hình 4. Bản đồ phân bố cấp độ tác động của TXx năm thời kỳ 2016-2035 theo kịch bản RCP4.5 (a) và RCP8.5 (b) tại khu vực có khoáng sản trên khu vực Việt Nam. 


\section{b) Lương mura 1 ngày lớn nhất năm (Rxlday năm)}

Theo kịch bản RCP4.5, vào đầu thế kỷ 21 , Rx1day năm phổ biến đạt cấp 2-4 ở vùng mỏ Tây Bắc, cấp 2- 6 ở vùng mỏ Đông Bắc, cấp 3-6 ở vùng mỏ Đồng bằng Bắc Bộ, Bắc Trung Bộ, cấp 5-6 ở vùng mỏ Nam Trung Bộ, cấp 2-6 ở vùng mỏ Tây Nguyên, cấp 4-5 ở vùng mỏ Đông Nam Bộ, và cấp 3-4 ở vùng mỏ Tây Nam Bộ. Theo kịch bản RCP8.5, vào đầu thế kỷ 21, phân bố phạm vi cấp độ tác động của Rx1day năm tương tự kịch bản RCP4.5 ở vùng mỏ Đông Bắc, Nam Trung Bộ, Tây Nguyên và đạt cấp 2-5 ở vùng mỏ Tây Bắc, 4-6 ở vùng mỏ Đồng bằng Bắc Bộ, cấp 3-6 ở ở vùng mỏ Bắc Trung Bộ, cấp 3-4 ở vùng mỏ Nam Bộ (Hình 5). Như vậy, trong quá trình khai thác và chế biến khoáng sản cần đặc biệt lưu ý đến cực trị mưa vào các tháng mùa mưa ở các mỏ thuộc Hà Giang, Yên Bái, ven biển Bắc Bộ, khu vực Trung Bộ, Đắc Lắc theo kịch bản RCP4.5; và lưu ý đến cực trị mưa vào các tháng mùa mưa ở các mỏ thuộc Đông Bắc Bộ và Trung Bộ theo kịch bản RCP8.5.
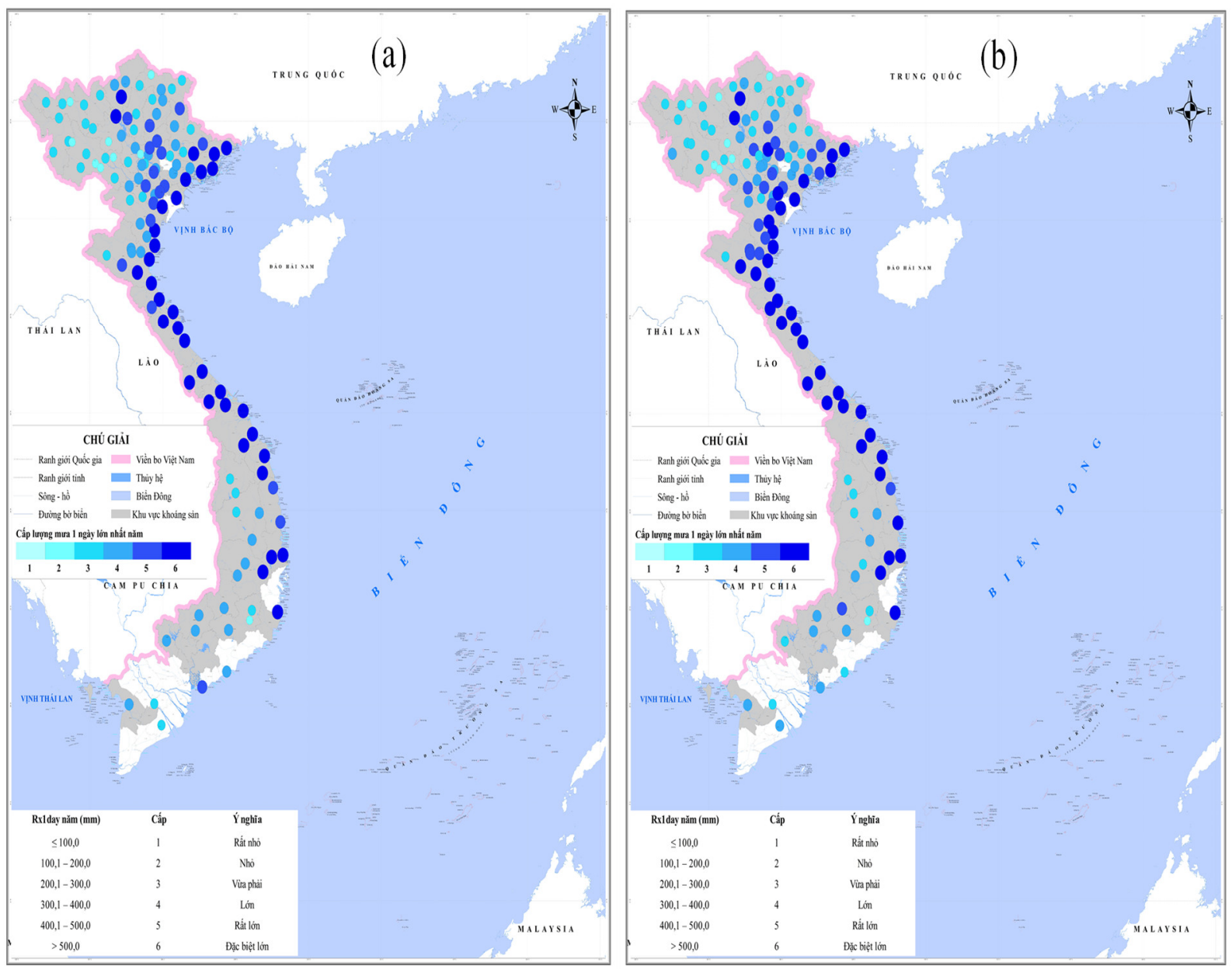

Hình 5. Bản đồ phân bố cấp độ tác động của Rx1day năm thời kỳ 2016-2035 theo kịch bản RCP4.5

(a) và RCP8.5 (b) tại khu vực có khoáng sản trên khu vực Việt Nam.

\subsection{Bản đồ nguy cơ ngập}

Khi mực nước biển dâng $100 \mathrm{~cm}$, các tỉnh có khoáng sản Titan-Zircon trên khu vực miền Trung đều có nguy cơ bị ngập (Hình 6). Trung bình tỷ lệ diện tích khu vực miền trung có nguy cơ bị ngập là 1,47\%. Các tỉnh có tỷ lệ diện tích bị ngập lớn nhất là Thừa Thiên Huế $(7,69 \%)$, Quảng Bình (2,64\%), Quảng Trị (2,61\%); nhỏ nhất là Bình Thuận $(0,17 \%)$, Ninh Thuận $(0,37 \%)$. 


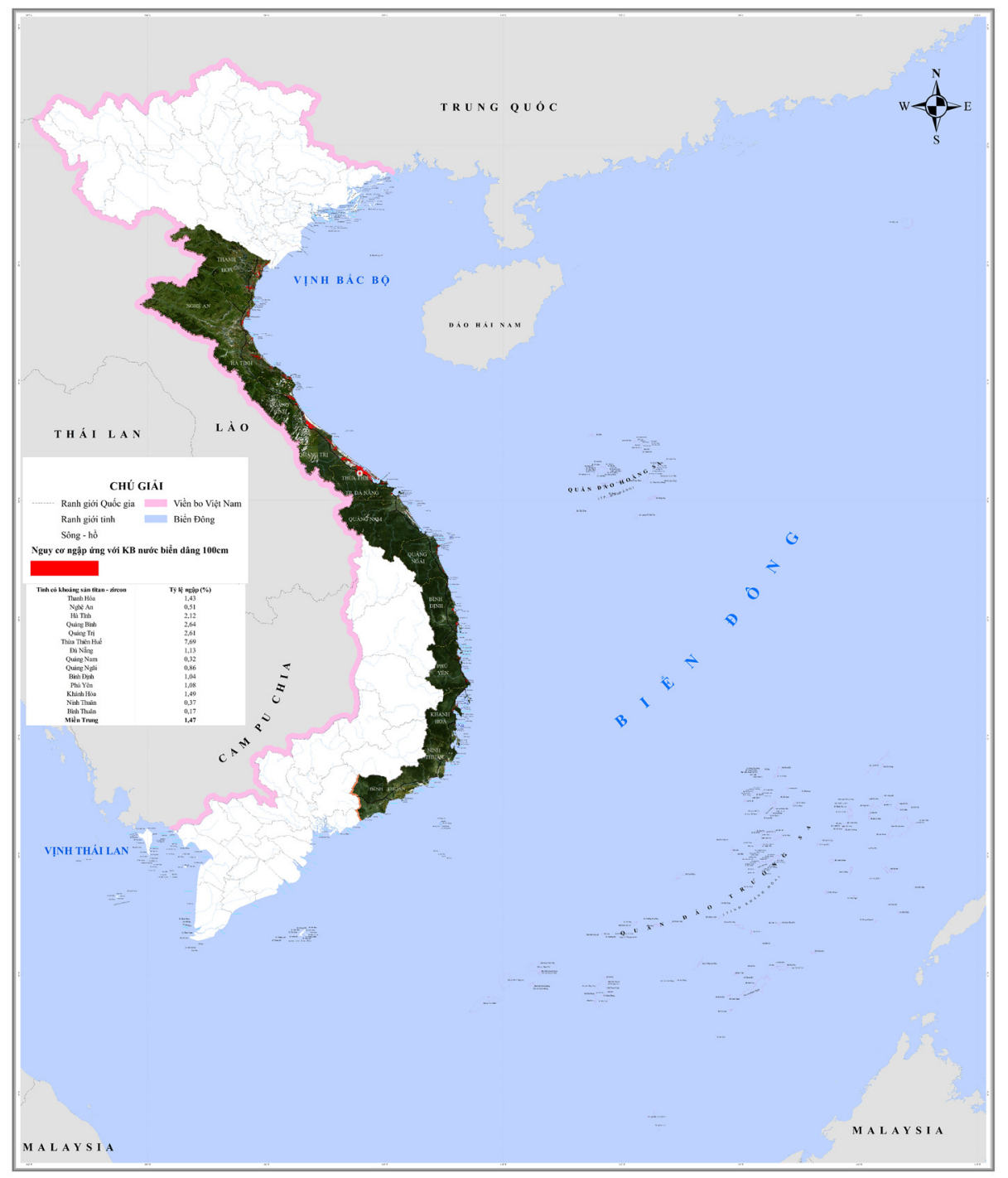

Hình 6. Bản đồ nguy cơ ngập ứng với mực nước biển dâng $100 \mathrm{~cm}$ trên khu vực miền Trung có khoáng sản Titan-Zircon.

\section{Kết luận}

Bộ bản đồ phân bố cấp độ tác động của BĐKH đến quy hoạch, thăm dò, khai thác, chế biến và sử dụng các khoáng sản chủ yếu ở Việt Nam được xây dựng dựa trên bộ số nhiệt độ, lượng mưa, nước biển dâng được lấy từ "Kịch bản biến đổi khí hậu và nước biển dâng cho Việt Nam" năm 2016; và dựa trên bộ bản đồ hành chính Việt Nam.

- Kết quả xây dựng cho thẩy, trong hoạt động quy hoạch, thăm dò, khai thác, chế biến và sử dụng các loại khoáng sản vào đầu thế kỷ 21 cần đặc biệt lưu ý đến:

+ Phòng chống lạnh ở một số nơi thuộc các tỉnh Lai Châu, Lào Cai, Sơn La, Lâm Đồng và cần có các biện pháp phòng chống nóng khi khai thác các mỏ thuộc Đồng bằng Bắc Bộ, Trung Bộ, Nam Bộ.

+ Phòng chống mưa lớn ở các mỏ thuộc phía nam khu mỏ Hà Giang và khu vực Thừa Thiên Huế-Quảng Ngãi.

+ Nhiệt độ cao nhất trong các tháng mùa hè ở Bắc Bộ và Trung Bộ.

+ Cực trị mưa vào các tháng mùa mưa ở các mỏ thuộc Hà Giang, Yên Bái, ven biển Bắc Bộ, khu vực Trung Bộ, Đắc Lắc theo kịch bản RCP4.5; và ở các mỏ thuộc Đông Bắc Bộ và Trung Bộ theo kịch bản RCP8.5.

- Đối với việc khai thác, chế biến, sử dụng khoáng sản Titan-Zircon cần đặc biệt lưu ý các biện pháp phòng chống ngập ở khu vực Quảng Bình đến Thừa Thiên Huế. 
Đóng góp của tác giả: Xây dựng nghiên cứu ý tưởng: N.T.H., V.V.T.; Lựa chọn phương pháp nghiên cứu: V.V.T., L.H.T., T.D.H; Xử lý số liêu: N.H.Q., T.T.T.T.; Viết bản thảo: T.T.T.T., N.H.Q., T.D.H.; Chỉnh sửa báo cáo: V.V.T., L.H.T.

Lời cảm ơn: Tập thể tác giả xin trân trọng cảm ơn Đề tài $\mathrm{KHCN}$ cấp quốc qia "Nghiên cứu xây dựng mô hình khai thác một số khoáng sản chủ yếu đảm bảo sử dụng hiệu quả, bền vững tài nguyên, bảo vệ môi trường và thích ứng biến đổi khí hậu”, Mã số: BĐKH.36/16-20 thuộc Chương trình "Khoa học và công nghệ ứng phó với biến đổi khí hậu, quản lý tài nguyên và môi trường giai đoạn 2016-2020”, mã số $\mathrm{BĐKH/16-20} \mathrm{đã} \mathrm{hỗ} \mathrm{trợ} \mathrm{về} \mathrm{số} \mathrm{liệu} \mathrm{và} \mathrm{phương} \mathrm{pháp}$ luận để thực hiện bài báo này.

Lời cam đoan: Tập thể tác giả cam đoan bài báo này là công trình nghiên cứu của tập thể tác giả, chưa được công bố ở đâu, không được sao chép từ những nghiên cứu trước đây; không có sự tranh chấp lợi ích trong nhóm tác giả.

\title{
Tài liệu tham khảo
}

1. Quý, N.Đ. Tiềm năng tài nguyên khoáng sản Việt Nam, Hội tuyển khoáng Việt Nam, 2013.

2. Ly, N.T. Biến đổi khí hậu ảnh hưởng đến môi trường địa chất, hoạt động khai thác khoáng sản ở Quảng Bình và giải pháp chế ngụ giảm thiểu, Tạp chí thông tin Khoa học \& Công nghệ Quảng Bình, số 1/2015.

3. Thanh, L.H. và cs. Đánh giá thực trạng khai thác từng loại khoáng sản chủ yếu hiện nay ở Việt Nam, thuộc Đề tài: "Nghiên cứu xây dựng mô hình khai thác một số khoáng sản chủ yếu đảm bảo sử dụng hiệu quả, bền vững tài nguyên, bảo vệ môi trường và thích ứng với biến đổi khí hậu, Chương trình Khoa học và Công nghệ ứng phó với biến đổi khí hậu, quản lý tài nguyên và môi trường giai đoạn 2016-2020, mã số BĐKH.36/16-20, 2018.

4. Thuy, T. T.T và cs. Ảnh hưởng của điều kiện khí hậu và biến đổi khí hậu đến thăm dò, khai thác, chế biến và sử dụng quặng bauxit trên các mỏ ở Việt Nam, Tạp chí Khoa học Biến đổi Khí hậu số 13-tháng 3/2020.

5. Thông tư số 47/2014/TT-BTNMT về "quy định kỹ thuật thành lập bản đồ hành chính các cấp", 2014.

6. Bộ Tài nguyên và Môi trường. Kịch bản biến đổi khí hậu và nước biển dâng cho Việt Nam, Nhà xuất bản Tài Nguyên Môi trường và Bản đồ Việt Nam, 2016.

\section{Developing distribution map of climate change impact levels on the planning, exploration, mining, processing and use of major minerals in Vietnam}

\author{
Truong Thi Thanh Thuy ${ }^{1}$, Vu Van Thang ${ }^{1}$, Nguyen Huu Quyen ${ }^{1 *}$, Nguyen Trong \\ Hieu $^{2}$, Tran Duy Hien ${ }^{3}$, Lai Hong Thanh ${ }^{4}$ \\ ${ }^{1}$ Viet Nam Institute of Meteorology, Hydrology and Climate change; \\ thuytruong021088@gmail.com \\ ${ }^{2}$ Science and Technology Center of Meteorology Hydrology and Environment; \\ hieu.nt38@gmail.com \\ ${ }^{3}$ Department of Science and Technology; tranhienvkttv@gmail.com \\ ${ }^{4}$ General Department of Geology and Minerals of Viet Nam; lhthanh@monre.gov.vn
}


Abstract: In this study, the data set of climate change and sea level rise scenarios published by the Ministry of Natural Resources and Environment in 2016 are used for study purposes. The results show that the planning, exploration, mining, processing and use of major minerals including coal, bauxite, lead-zinc, cement limestone, white limestone, kaolinite, feldspar, apatite, Stone as a common building material should especially note cold prevention measures in Lai Chau, Lao Cai, Son La, Lam Dong and heat prevention measures in the Northern Delta, Central regions, Southern region; heavy rain prevention measures at mines in the south of Ha Giang mine and in Thua Thien Hue to Quang Ngai areas. Besides, this study should note high temperature during summer months in the Vietnam North and Central regions, rain extremes during rainy season months at mines of Ha Giang, Yen Bai, Northern coastal area, Central region, Dak Lak under the RCP4.5 scenario and at mines of Northeastern and Central regions under the RCP8.5 scenario. For the planning, exploration, mining, processing and use of Titan-Zircon, special attention should be paid to the risk of flooding in the Quang Binh to Thua Thien Hue areas.

Keywords: Map; Climate change; Mineral; Vietnam. 